Iván I. Rincón Borrego
Figure 1. Harald Sohlberg. Winternight in Rondane, 1914. (Norberg Schulz 1996: 11).

Doctor Arquitecto por la Escuela Técnica Superior de Arquitectura. Universidad de Valladolid.

\title{
Landscape architectures in Norway The influence of AHO masters on the National Tourist Routes of Norway
}

Keywords: Landscape architecture, Norway, AHO, Knut Knutsen, Christian Norberg Schulz, Svere Fehn

During the 1990s the Norwegian government developed the National Tourist Routes Plan, focusing on upgrading 18 local road routes. The interesting program involved thoroughfares designated for road vehicles, bringing about the recovery of the epic sense of car road trips, access to remote spots, and sustainable enhancement of their value. Many of the projects were carried out by young Norwegian architectural and landscaping teams trained at the Oslo School of Architecture and Design (AHO) under the influence of Knut Knutsen, Christian Norberg Schulz, and Svere Fehn. Through analysis, the objective of the research is to unravel the links between these landscape projects and the thought of the AHO masters.

\section{Introduction}

The endless plain upon which I stood was bathed in half-light and mysterious shadow. I saw deformed, twisted and overturned trees, mute indications of nature's inconceivably powerful forces, for the storm's might and fury. (...) Before me in the distance rose a range of mountains, beautiful and majestic in the moonlight, like petrified giants. The scene was the most magnificent and filled with fantastic stillness that I have ever experienced. Over the white contours of a Nordic winter stretched the sky's endless vault, filled with myriad glimmering stars. It was like a holy service in a great cathedral. Winternight in Rondane (1914), Harald Sohlberg (Norberg Schulz 1996: 11).

Nature is imposing and majestic in Norway. From the sudden outcrops of rocks that break up the dark coast of Varanger to the natural amphitheatre formed by the fiords of Sognefjellet, the scenery alternates among forests of impenetrable thickness,

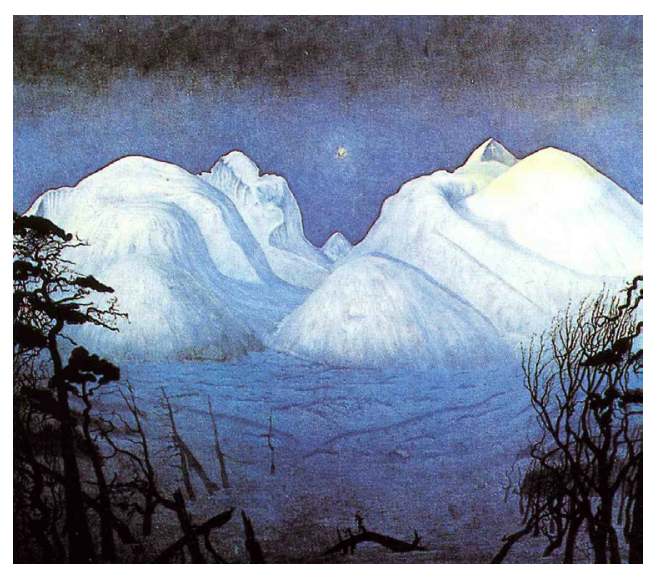

glaciers impossible to encompass at a glance, mountain peaks of perpetual snow, tundra and icefalls, all bathed in the diffuse tones of the mists and the glow of the midnight sun. A sublime and mercurial beauty.

Since time immemorial, nature in Norway has been the source of life for its inhabitants and the inspiration for their beliefs. The extremely rugged landscape, together with the extremes of climate, has pushed them to face the environment to ensure their survival. But at the same time, this has impregnated the Scandinavian character with a sense of respect, almost veneration, for the mysteries found in Midgard -the world Odin and his brothers Vili and Ve created for humankind to live in- which drives the denizens to venture into its most inhospitable locations.

\section{Towards National Tourist Routes Plan of Norway}

Norwegian literature and art are teeming with brilliant examples of this feeling. Beginning with the odyssey of Peer Gynt (1876) written by Henrik Ibsen (1828-1906), an uncontrollable traveller if there ever was one, and continuing through the novels of Knut Hamsun (1859-1952) -for example, Pan (1894) and Growth of the Soil (1917)- Norwegian literature has cemented the myth of the solitary Scandinavian traveller, who feels lost in civilization, constantly attracted by the irresistible call of native forests.

The painter Harald Sohlberg (1869-1935) crafts an image of this call in Winternight in Rondane (1914), a doorway that leads him to the Blue Mountains (figure 1). Under the cold northern light, the scene is presented 
in layers of shadow that shroud the forests while the snow-capped mountain ranges in the background glow enigmatically from the reflection of the moon, which makes them ghostly apparitions. The vision, far from being troubling, calms the painter after having seen "deformed, twisted and overturned trees, mute indications of nature's inconceivably powerful forces, for the storm's might and fury. (...) Before me in the distance rose a range of mountains, beautiful and majestic in the moonlight, like petrified giants." The scene highlights a sublime perspective of Norwegian nature. But even more than this, it reveals the artist's own experience, the roving restlessness of the modern Scandinavian individual, of the wanderers that live to the extent that they discover exciting unexplored settings, places where they become self-aware in the escape.

In 1975 the historian Robert Rosenblum published his study on the evolution of scenery in painting, Modern Painting and the Northern Romantic Tradition: Friedrich to Rothko, (Rosemblum 1993), ranging widely from the Romanticism of the 19th century to the Abstract Expressionism of the mid-1900s. This study moulds the concept of the abstract sublime; panorama as origin and basis, the romantic vision as a seed of the more modern vision. While it is true that the romantics taught us how to look at the scenic view, the landscape is no longer the frame for a scene, it has become the scene itself.

Like literature and art, Norwegian architectural culture has also been nourished by the indisputable natural heritage surrounding it, especially throughout the 20th century. Many Scandinavian architects and theorists have linked a good part of their output to this landscape, a legacy that has also been transmitted positively to architectural students around the country, fundamentally in the Oslo School of Architecture and Design (AHO). Proof of this is the Norwegian National Tourist Routes Plan, a programme which, together with the ambitious Oslo Fjord Plan, both symbolise the change of a whole new generation of young architects in Norway. ${ }^{1}$

The Norwegian National Tourist Routes Plan was launched by the National Administration of Norwegian Roads to regenerate 18 roadways along the country's coast using small-scale scenic and architectural projects. By 2023, 250 initiatives will have been completed, making it one of the most extensive landscape intervention programs in contemporary culture (Rønning 2016). ${ }^{2}$ Jonas Gahr Støre expresses that the essence of this chan-
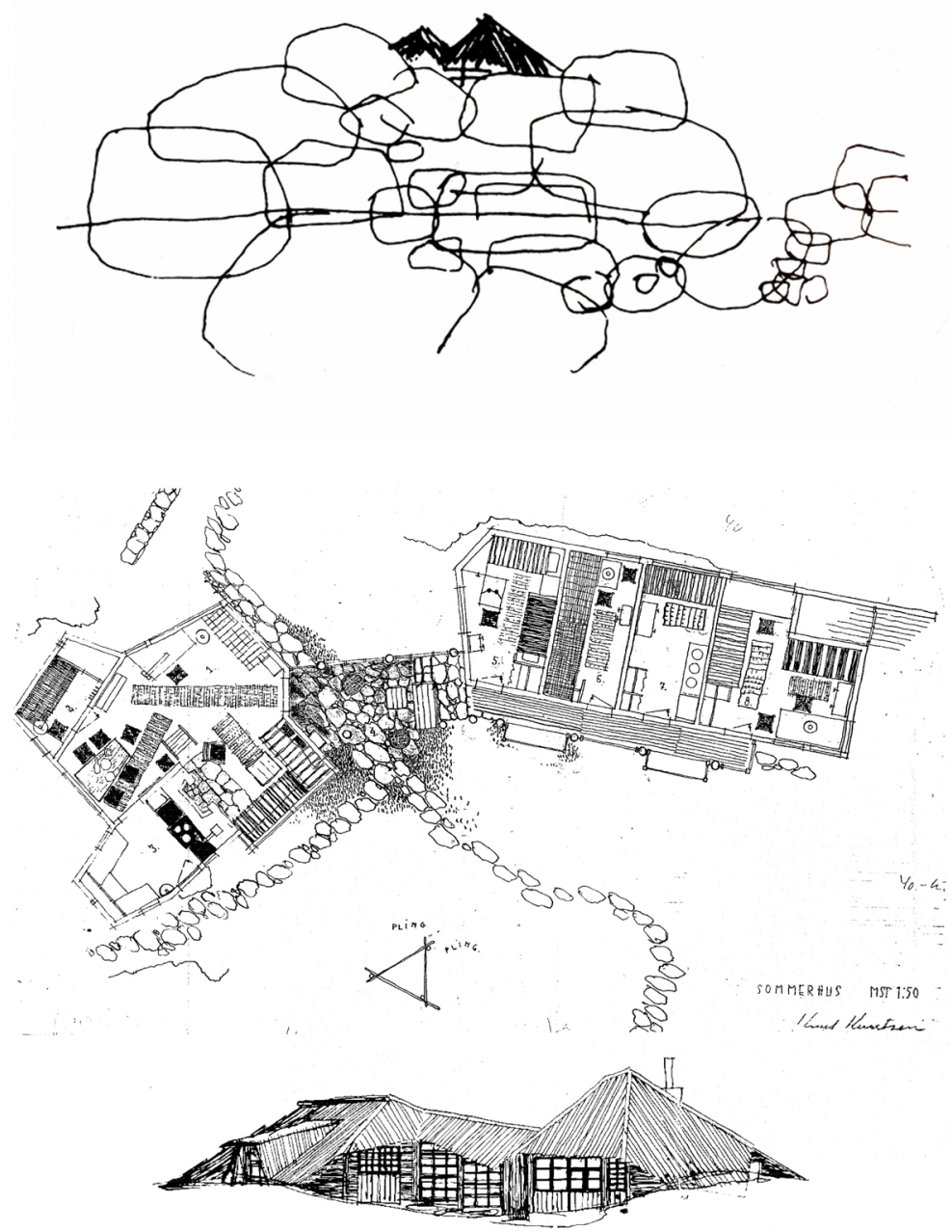

ge is basically generational. He underlines the idea of Norwegian architecture as a way to tell stories and explain places and the world. ${ }^{3}$

Figure 2. Knut Knutsen. Summer house in Portor, 1949. (Knutsen 1952: 126).

\section{The Influence of the Oslo School of Archi- tecture Masters}

\section{Knut Knutsen}

One of the first authors to sense the advantageous dialog between architecture and the environment was the architect AHO professor Knut Knutsen (1903-1969). In his 1961 text People in Focus he tells us how he always tried to teach his students during his classes that every "building -it can be a really good one- will always be weakened by its surroundings if there is no connection between them." (Knutsen 1961: 248). Words that emphasize the idea that constructing is far from subordinate to the environment (that is, leaving it untouched); it should rather become involved with it to enhance it and make it visible: "Respect and reverence for a landscape must 

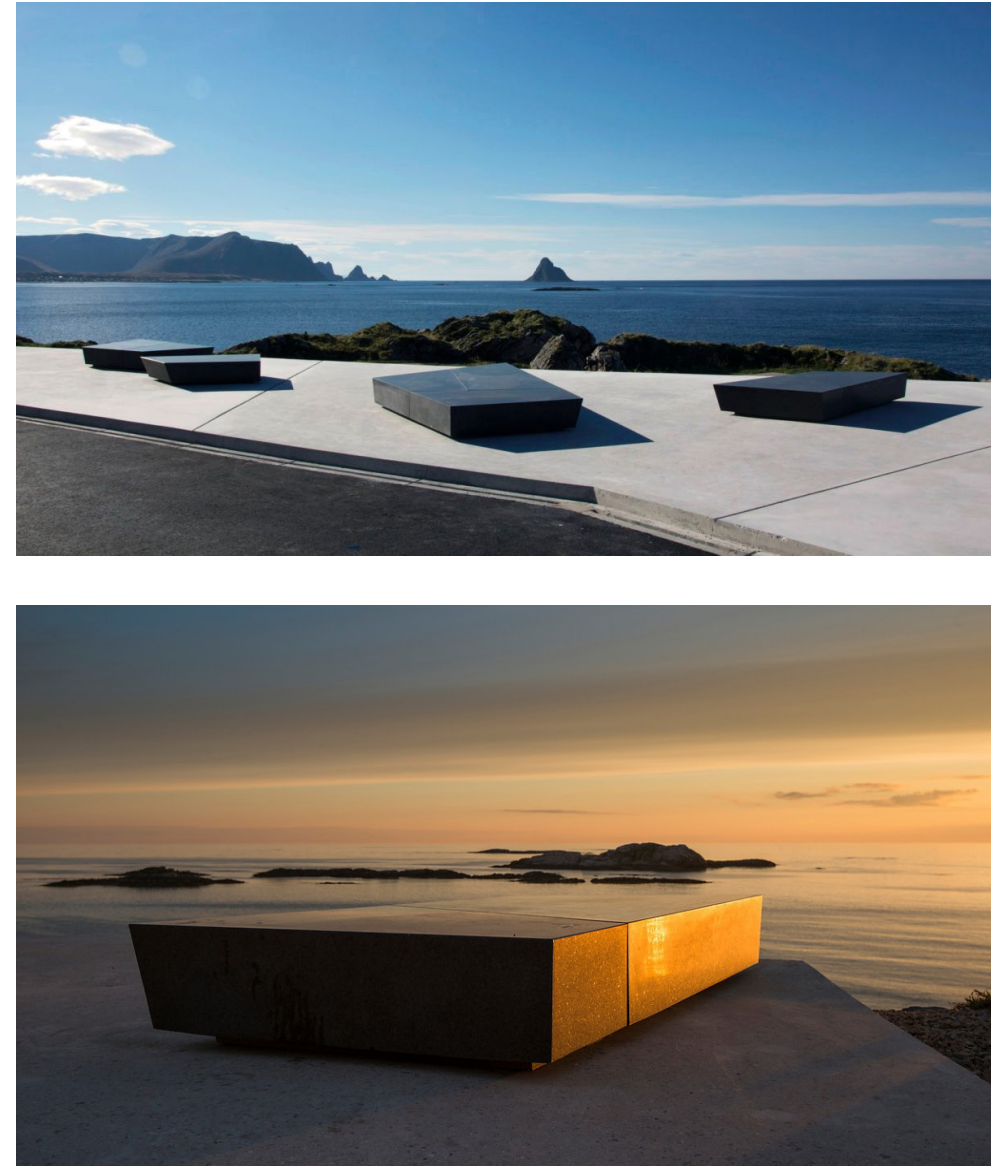

Figures 3 and 4. Inge Dahlman. Kleivodden viewpoint, 2013. (Vi1lalobos 2018: 36).

Figure 5. Code Arkitektur. Tungeneset viewpoint, 2008. (Vi1lalobos 2018: 38)

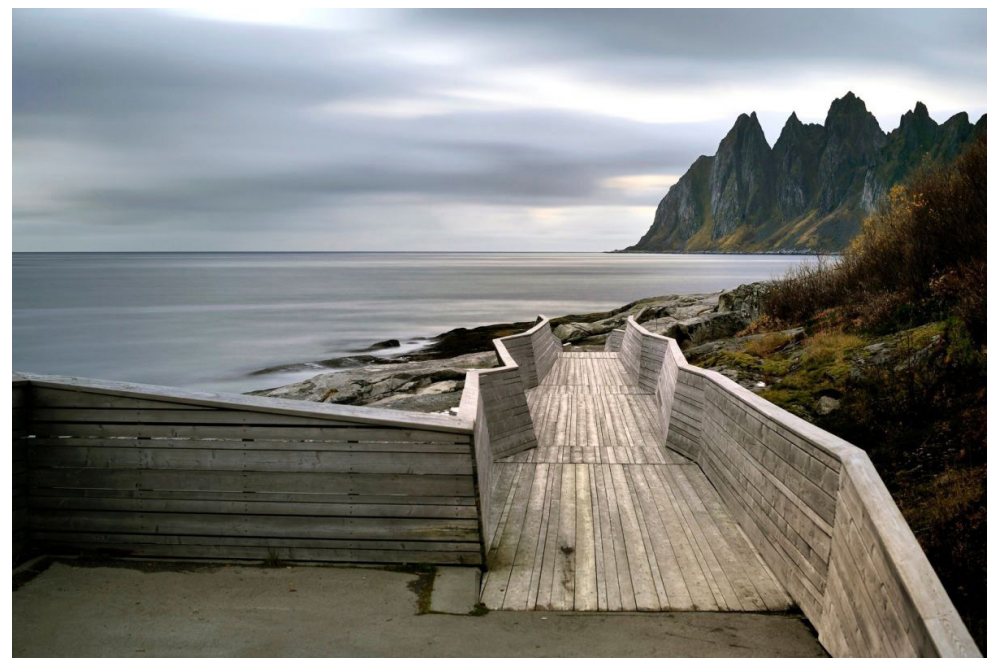

them in that it hides from indiscrete glances, attempting to leave the setting intact. It follows a strategy of "insertion between things." (Nicola Flora 1999: 43). The floor plan is divided into two small masses that seem like a natural feature; these volumes are minimized using slanted dark wooden roofs that emerge from the ground among trees and granite bluffs, giving the entire house, a geomorphic look (Knutsen 1952: 126-129), (figure 2).

In that sense, several scenic viewpoints built within the National Tourist Routes Plan framework are worthy representatives of the postulates upheld by Knut Knutsen. The first is the Kleivodden viewpoint on the island of Andøya (2013), on the north coast of Norway. The landscape architect Inge Dahlman, ${ }^{5}$ planned a project of great restraint and sensibility at the edge of the sea. The place is close to the Andøya Rocket Range, a facility today renamed Andøya Space Center (ASC) that has been used since the 60's for the launch of stratospheric balloons. The team designed an angular concrete platform from which four blocks of black Lødingen granite emerge. Its pointed shapes guide the visitors toward the wide maritime view that opens in front of them, while its sharp, polished look mixes with the sophisticated rock crystals that appear on the surface from the passage of time. Formal exercise is reduced to a minimum. Everything is aimed towards the sea, not only the organization of the car park, but also the concrete promenade, as well as the furniture that looks like abandoned rocks. Therefore, the place is re-qualified as an excellent point from which to observe the Aurora Borealis, emphasizing the sense that links it to the original space project itself (figures 3 and 4).

A second vantage point linked to the manner Knutsen understands the place is that of Tungeneset, lies on the tip of the promontory that separates the Steinsfjord and the Ersfjord (2008). The Code Arkitektur studio designed a light structure of steel and wood platforms resting gently on the terrain. Its lines flirt with each other as they descend toward the sea, establishing an intense formal dialog with the steep mountain peaks in the background. The layered wood walkway evokes the whimsical course of the cost, the angular walkway shapes recalling the geological folds that have formed the coastline. The construction dramatizes the experience of the location and the view, (figure 5).

In this sense, the architects Jensen and Skodvin ${ }^{6}$ stand out for one of the first inter- 

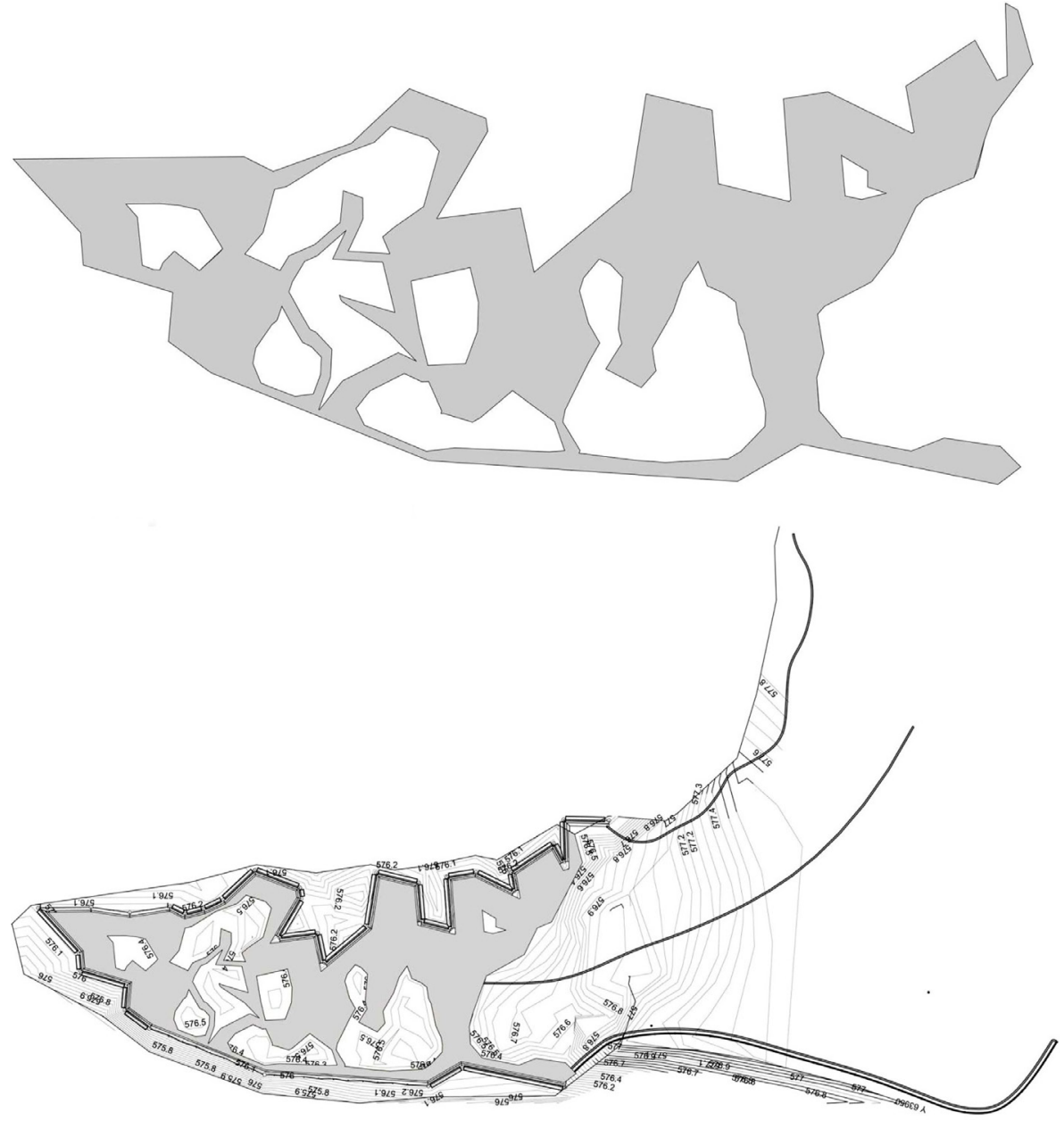

ventions of the National Tourist Routes Plan, the viewpoint over the Videfossen waterfalls (1997). It is a structure of concrete and reinforced steel plates suspended over the waterfall giving the impression of being on the riverbed just when gravity breaks it. The structure is designed to support the impact of frequent avalanches of snow that occur in the area, it behaves like a topographical recreation of regularized rock. From a formal point of view, the planes acquire angles presented in the drawing of the handrail that varies from the lightest elements, at the beginning of the walk, to the heaviest steel plates point-welded, just above the waterfall and the precipice. The solution stops avalanches but leave the view unobstructed acting as snow barriers during especially snowy winters. The result is a combination in which the rhythm of the natural form of water and rocks echoes in the rhythm of the built forms, (figures 6 and 7 ).

These designs mentioned share an attitude evoked by Sverre Fehn himself in explaining Knut Knutsen's work: "It was his love for "the whole" that gave his relation with nature new dimensions, while the key to understanding the formal expression of his architecture lies in his reading of the lay of the land", (Sverre Fehn 1999: 126). Knutsen's ideas, espe-
Figure 6. Jensen and Skodvin. Viewpoint at Videfossen waterfalls, 1997. (Ref. web 2: www.jsa.no).
Figure 7. Jensen and Skodvin. Viewpoint at Videfossen waterfalls, 1997. (Ref. web 2: www.jsa.no).

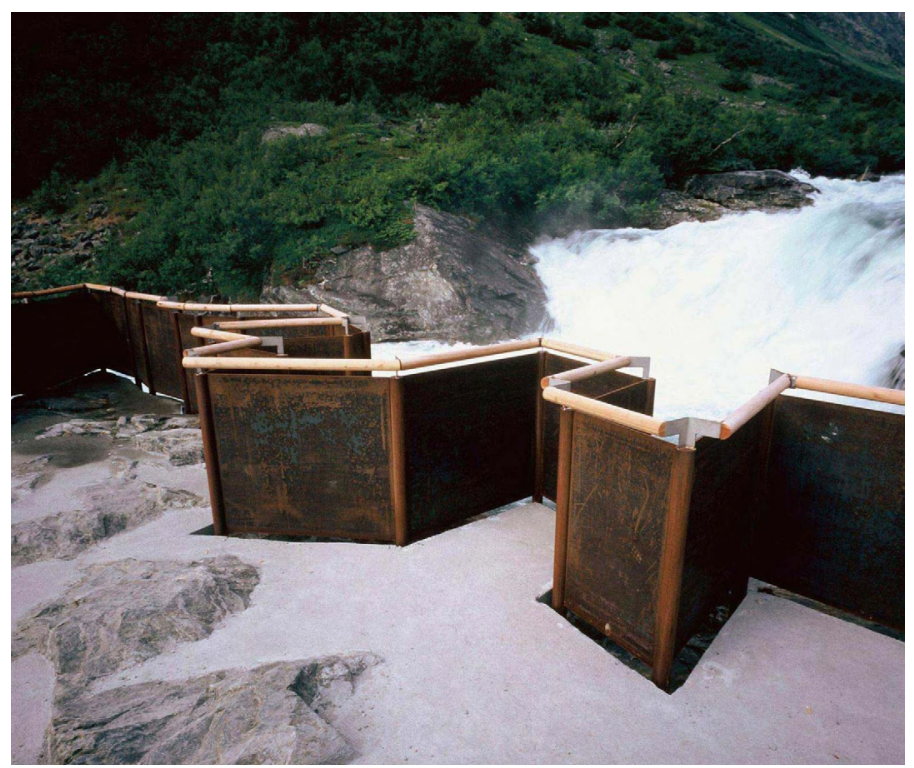



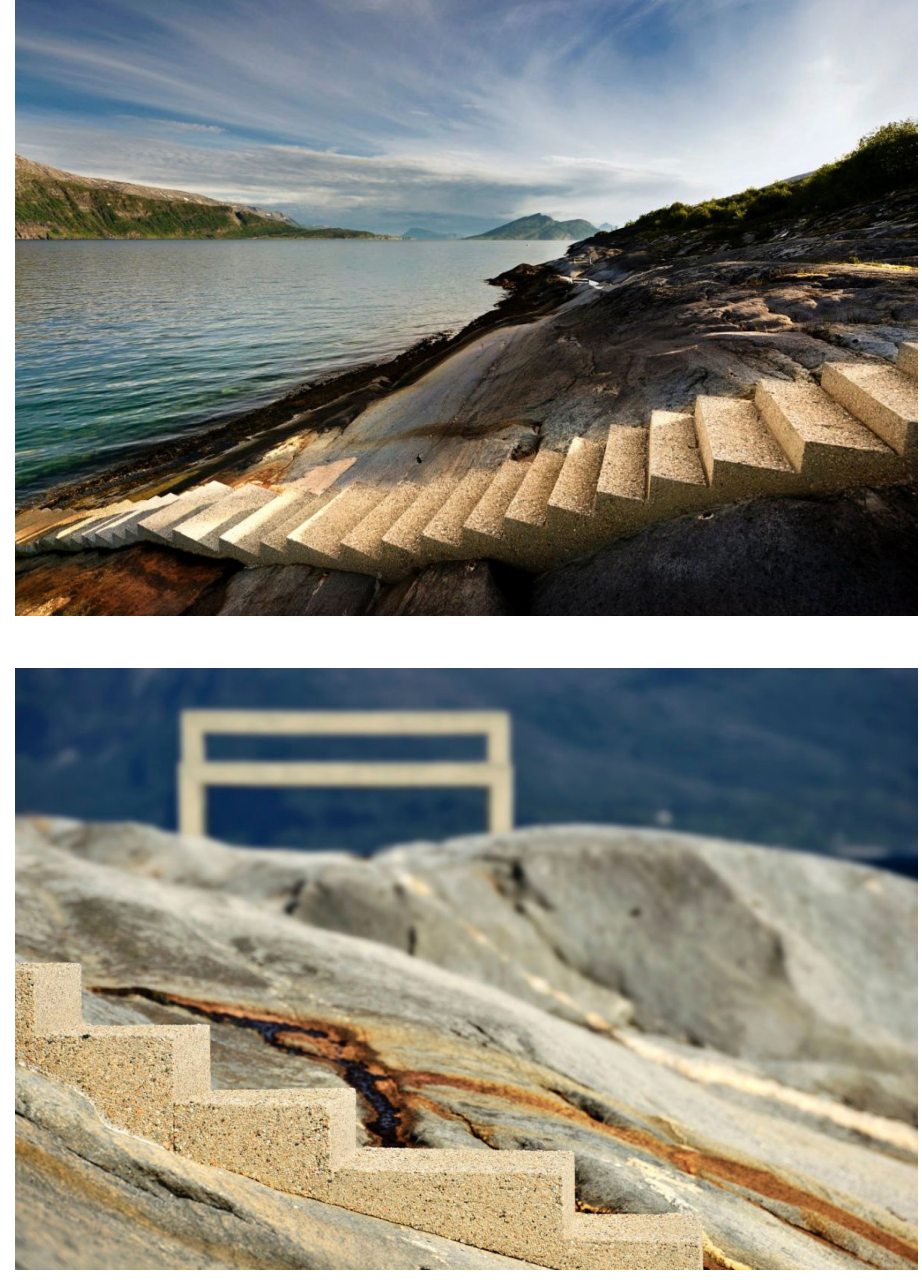

Figures 8 and 9. Arild Wåge (Nordplan-AS) and Igne Dahlman. Hellåga viewpoint, 2006. (Ref. web 2: www.nasjonaleturistveger.no). cially those expressed through his house in Portor, set up parallelisms between the forms of nature and the language of human creation. A kind of formal analogy that is also present in the above-mentioned interventions, as they adopt forms that evoke the natural environment in an abstract way.

\section{Christian Norberg Schulz}

The theorist and historian of architecture who best represents Norwegian sensitivity toward its own landscape is Christian Norberg Schulz (1926-2000), an AHO professor of architecture theory and history since 1966. Books such as Intentions in Architecture (1963) and Existence, Space and Architecture (1971) constitute the basic works in a prolific output in which he fashions concepts still detectable today in the youngest Norwegian architects: the ideas of existential space and genius loci. Existential space is defined as " $a$ relatively stable system of perceptive schemes or 'images' of the surrounding environment" (Norberg Schulz 1975: 19), a backdrop of human actions made up of the meanings of the ordinary codified by means of architecture. This becomes the second concept, the genius loci or principle of identity of place, when applied in a territorial scale

According to Norberg Schulz, the codes of nature are what make the architect conscious of the setting. These codes are divided into categories: "object, order, character, light, and time" (Norberg Schulz 1975). The first two have to do with spatial qualities, and the following two categories refer to the atmosphere of the setting. Finally, the last -time-alludes to the idea of constancy and change inscribed in the eternal cycle of time. Sensitivity toward these codes makes the architectural space a participant in a live event represented as a specific setting, as a genius loci, an existential reality born in the landscape. Natural events respond to the idea of place present in the ancient theory of the universe where the sky, land, rocks, trees, and water (that is, the primary "things") mark settings filled with meaning for the architect (Norberg Schulz 1979: 24).

In the book Principles of Modern Architecture. About the new tradition of the 20th century (2000), Norberg Schulz translates the existential concepts of genius loci to architectural concepts associated with the identity of place. The Scandinavian historian views the principles of "visualization" and "complementarity" as project strategies worthy of consideration (Norberg Schulz 2000: 187).

According to the visualization principle, buildings tend to repeat and emphasize the features of a specific setting. An example would be a city carved into the heights of a hill, which reveals the topography inherent to the rock on which it is set. This principle is used by Arild Wåge, ${ }^{7}$ from the Nordplan-AS team of architects, together with Igne Dahlman, in the Hellaga viewpoint on the Helgelandskysten route (2006). The Hellagga rest area lies by the Sjonafjord, with steps that curve gently down the steep rocks to the water. The design reflects the long lines of the mountain formations on the other side of the fjord, as well as improves accessibility to the water's edge. Visitors are guided down to the sea below through an enigmatic granite stairway carved out over the granite coast, coming to an end in the sea, which is poetically blurred by the action of the tides and waves. According to the visualization principle, the stairs emphasize the material the coast is made of and vice versa, both of them sharing the same fate from nature's actions, (figures 8 and 9). 
In contrast, the complementarity principle is a strategy in which the buildings intentionally seek to oppose the features of their surroundings, in order to establish a meaningful link between the two. The rammed-earth fortresses in southern Morocco are a good example; they delimit enclosed spaces against the undifferentiated immensity of the desert. The National Tourist Routes Plan also includes notable projects that use this strategy.

The rest area designed by Reiulf Ramstad in Selvika (2012) is the first of two cases we can consider. ${ }^{8}$ It is located on the route from Kokelv to Havøysund. A heavy concrete structure snakes its way from the road to the sandy Sandbukta beach inviting the visitor to explore landscape from various perspectives. From a distance, the rest area looks like a grey concrete sculpture with references to the rock formations in its environment. But walking its interior, the architect contrasts the openness of the marine horizon with the architecture formed by curved concrete spaces that surround the visitors, (figures 10 and 11).

The Stegastein viewpoint (2005) in Aurland, one of the largest fjords on Norway's west coast, has been designed by architects Todd Saunders and Tommie Wilhelmsem, and is probably one of the most well-known and recognisable works of the National Tourist Routes Plan. The idea was to build a viewpoint that leaves landscape untouched, but at the same time gives an illusion of hovering in space as it reaches 30 metres out over the pine trees; an impressive experience facing the attraction of the abyss, 650 metres above the Aurlandsfjord, where visitor is driven "to the limit of visual intensity" (Álvarez-Álvarez 2017: 15). In order to do this, a 4-meter wide footbridge is built with a metal structure and covered with timber. Thanks to the only two points of support on the slope, the element seems to be suspended on the landscape, drawn on the sky. In order to make the effect more intense, its shape curves downwards like a vertical toboggan, ended only by a glass that prevents the fall of the viewer. The result is a wonderful frame of the village at the bottom of the fjord, (figures 12 and 13).

Conceptions mentioned above, those of Hellagga, Selvika and Stegastein, share the common goal of transforming the design into a meaningful enclave. Their designs work with the quoted ideas of existential space and genius loci highlighting the idea of architectural space as a premature intuition of place.

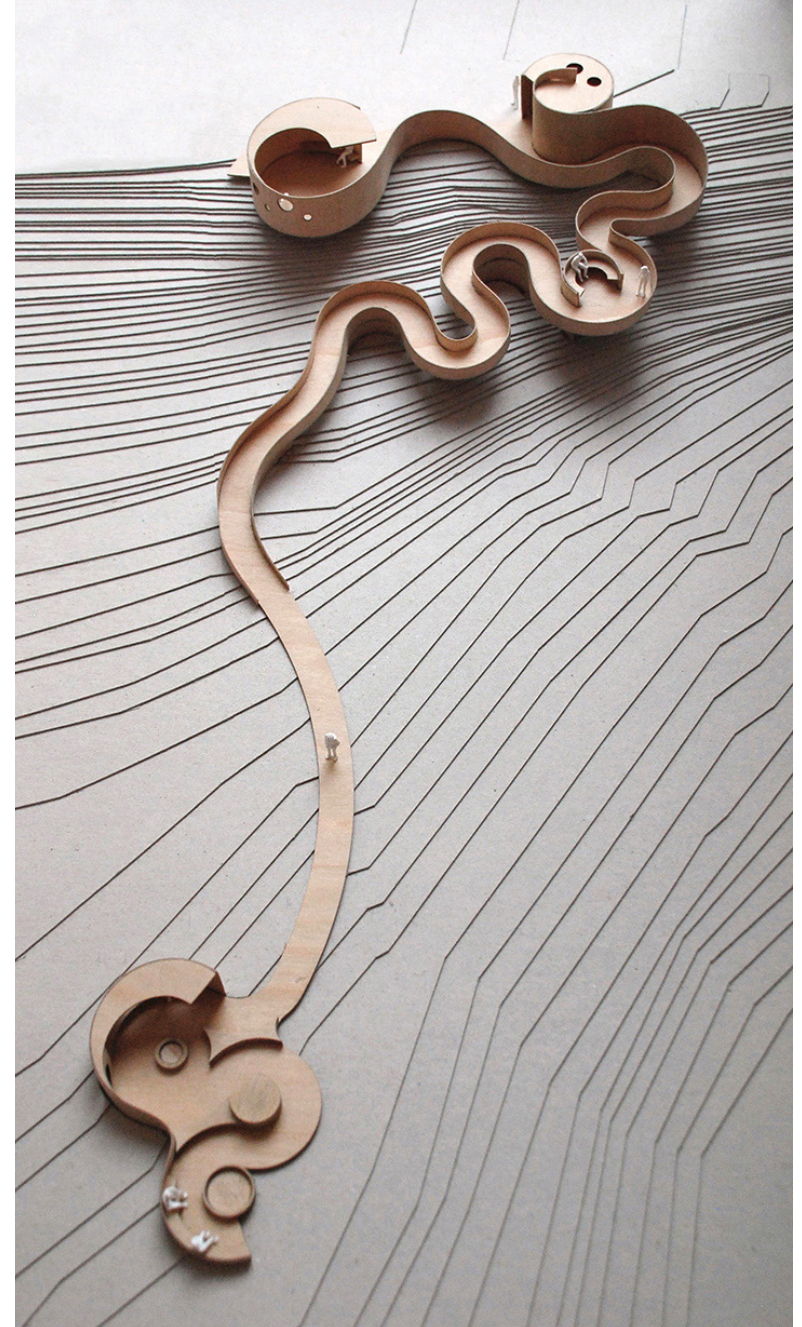

The architectural space defined by Norberg Schulz is composed of attributes, relationships and processes that are sensed by the body, in other words, by qualities. (Norberg Schulz 1971: 19) Martin Heidegger's philosophy is key to understanding this notion because of his ability to bridge the intellectual gap between man and his environment. (Norberg Schulz 1971: 16) For him, architecture

Figure 10. Reiulf Ramstad. Selvika rest area, 2012. Model. (Ref. web 2: www.reiulframstadarchitects.com).

Figure 11. Reiulf Ramstad. Selvika rest area, 2012. (Villalobos 2018: $41)$.

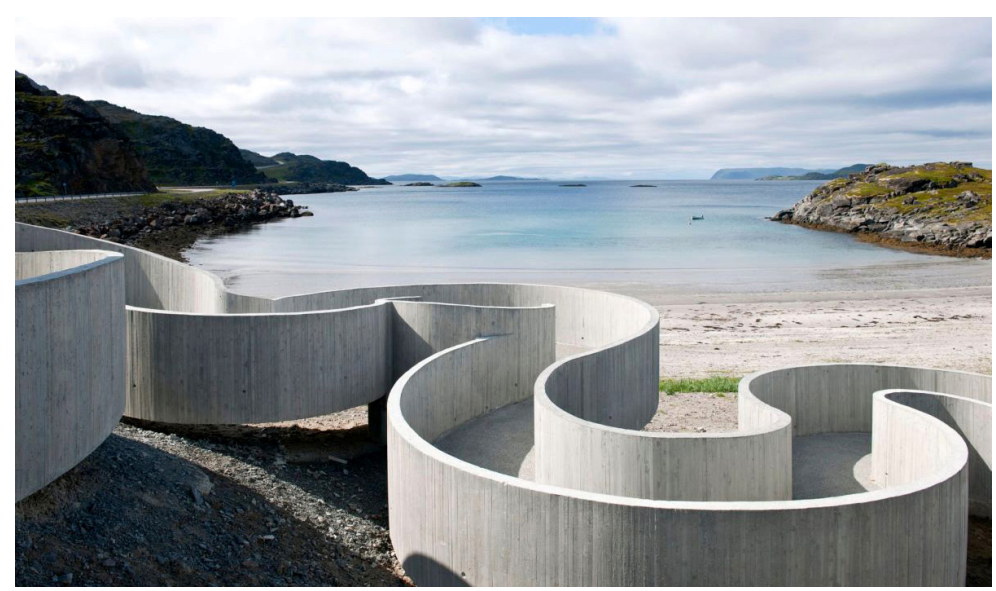



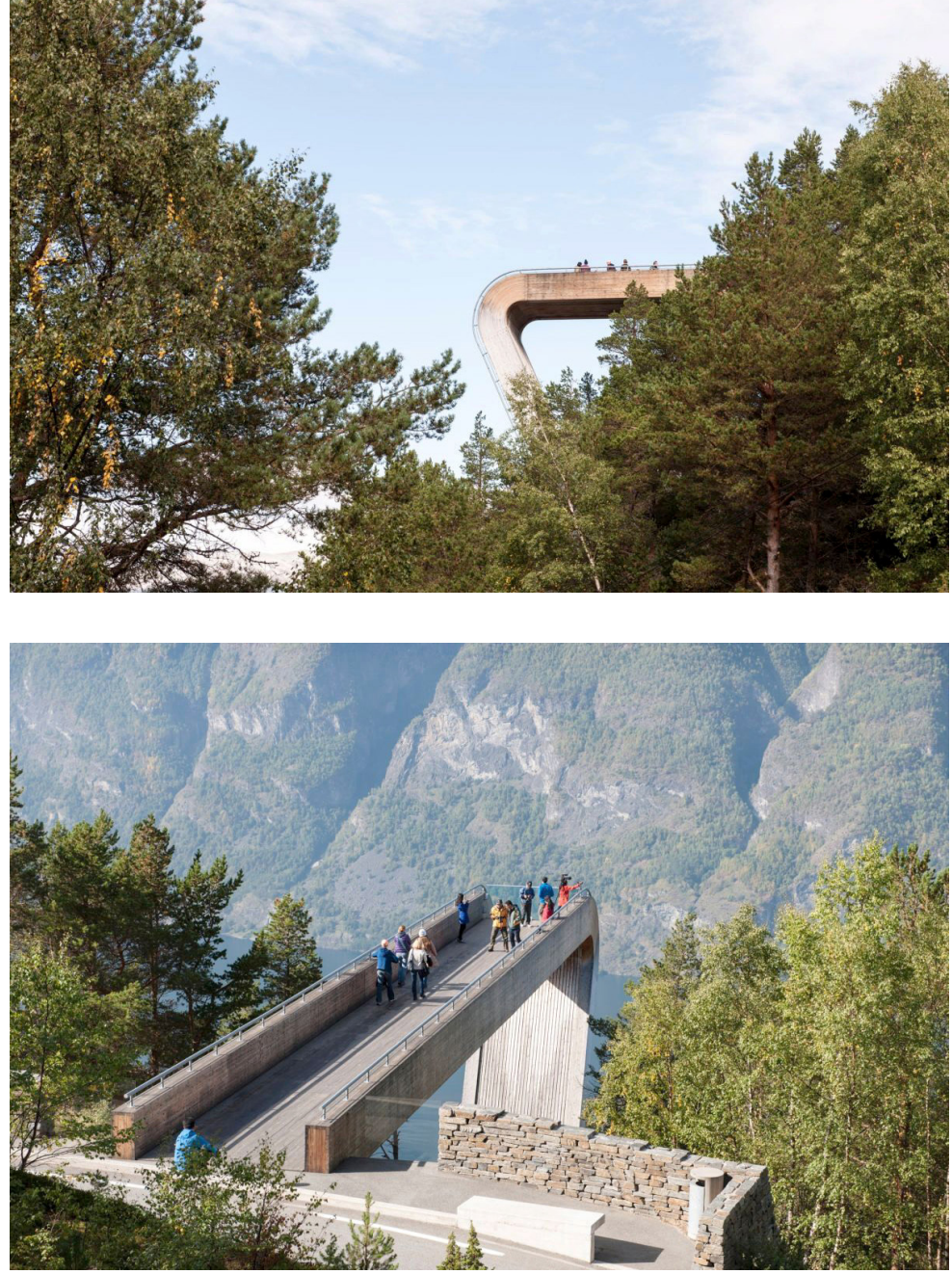

Figure 13. Todd Saunders and Tommie Wilhelmsem. Stegastein viewpoint, 2005 (Villalobos 2018: 22)

Figure 14. Sverre Fehn. Norwegian Glacier Museum, Fjærland, 1989-91. Sketch of the building in landscape. (Source: The National Museum of Art, Architecture and Design, Oslo). may have the purpose of responding to this need for orientation. Subtracting importance from the purely visual and rational aspects of the architectural space, promotes its conception as a place capable of impelling the visitor's action in the landscape. To draw a point of departure or arrival, to establish an enclave where to stop along the way or a place of rest, are qualities present in the mentioned examples of the National Plan of Tourist Routes influenced by the ideas of Norberg Schulz.

\section{Sverre Fehn}

The foremost author for the current generation of Norwegian architects is Sverre Fehn (1924-2009), an AHO professor since 1971 and the only Norwegian architect awarded the Pritzker Architecture Prize (1997). The considerable legacy of this author is remarkable both because of his work and because of his way of explaining it. Fehn considered that the teacher-architect's task is to narrate the world and its constructions, to explain their raison d'être, consequently nourishing the knowledge of those who listen; because teaching architecture also creates it, and only in this way -creating- can others be helped to imagine it. As in the tradition of the Viking sagas, this author created fables for his students. With them, he symbolized architectural resources based on rhetorical figures, especially environmental analogies and metaphors. Examples are the structures of the sky and the sea linked by the horizon, the flight of birds against the diving of fish, and the shadowless light of the midnight sun, all figures that he applied to architecture and place. ${ }^{9}$

An exceptional case in that sense is his fable The Skin, the Cut \& the Bandage (Fehn 1994), which he adapts to include in the opening conference at the Pietro Belluschi Lectures at the Massachusetts Institute of Technology (MIT). Using the same plot Fehn weaves most of his projects together in this speech, thanks to the use of the three concepts that give rise to its title, applied to the relationship between the building and the landscape. First of all, we find the Skin, understood to be the surface layer that covers the Earth's crust and houses the footprints left by humans and cultures as they pass by. Next comes the Cut, embodied in the crevices in the land, in whose depths time and memory slip in. And finally, we have the Bandage, which is the architectural layer: the buildings that cover the skin and suture the cut or, to put it in other terms, that emphasize the meaning of the setting.

Much of Fehn's work, especially his museum projects, incorporate these symbolic concepts. They are found in projects such as the Vasa Museum in Stockholm (1982), which sinks into the Earth's skin; in others like the Røros Museum-Olav's Mine in Sør-Trøndelag

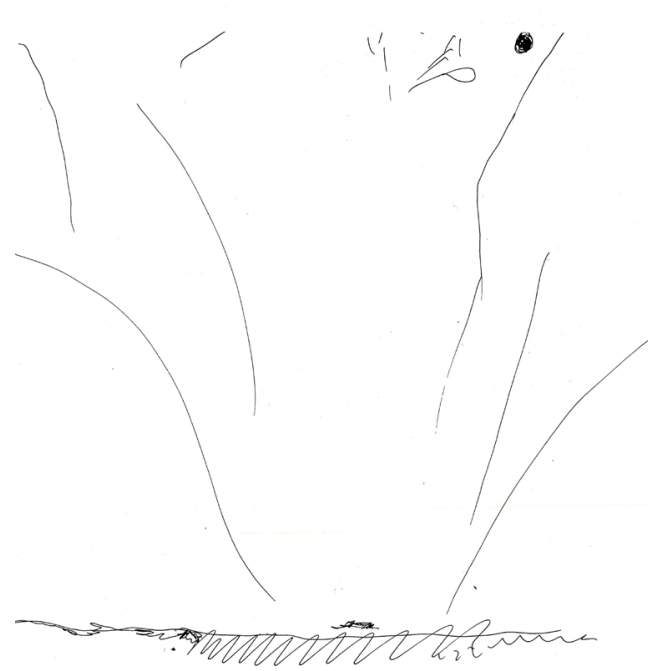


(1979-80), which sutures the incision in the land that the Glåmma River represents; or, finally, in the Norwegian Glacier Museum in Fjærland (1989-91), which marks the exact spot from which to contemplate the largest glacier in Europe, "like an altar in a great cathedral, as the nature is, with mountains for walls and the sky as the roof." (Fehn 1994: 30), a plinth among the immensity of the walls of rock in which to feel the dimension of the stay in the panorama (figures 14 and 15).

Sverre Fehn pays special attention to architecture conceived from a bird's-eye view through the idea of Tattooing (Fehn 1994: 34), a variation that straddles the line between the Cut and the Bandage, an imprint that is simultaneously an extension of the skin and a new layer of meaning deposited on it. His drawing entitled "The Globe and the Arm" portrays the architect as a tattoo artist working on the Earth (figure 16). His architecture, accordingly, could be understood as a footprint left on the landscape, a creation that participates in both the land's spatial component and in its meanings, a construction carved into the Earth's crust.

There can be no doubt that Land Art influenced the story of The Skin, the Cut \& the Bandage. Following a path parallel to that of the show Earth Works (1968), the Norwegian's fable redefines the action on the landscape by cancelling the objective value of the work in favour of the guiding process of the land that nurtures the intervention, as well as its observation from above. Works such as Line in Tula Desert (1969) by Walter de Maria, Double Negative (1969-70) by Michael Heizer, and Relocated Burial Ground (1978) by Dennis Oppenheim, (figure 17) among others, exemplify eloquent interchanges of counterparts between landscape and architecture, with a sensitivity that Sverre Fehn made his own and transmitted to his students. This is illus-

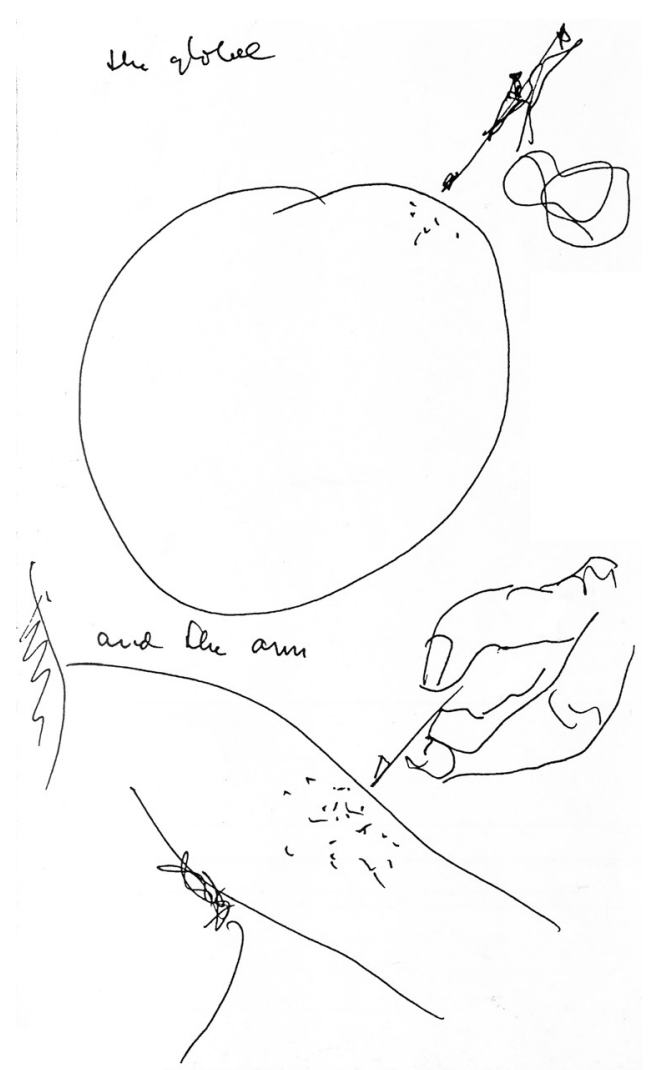

Figure 16. Sverre Fehn. The Globe and the Arm, non dated. (Source: The National Museum of Art, Architecture and Design, Oslo).

trated by his reference to the German artist Hannsjörg Voth (an inspiration for him), close to American Land Art during his speech at MIT: "I don't remember why but, when designing the Glacier Museum, I was thinking also about a big figure, wrapped in cloth, made by the German artist Hannsjörg Voth. (...) I looked and looked at pictures of it." (Fehn 1994: 29). ${ }^{10}$ Hannsjörg Voth's work is composed of what are called "Zero landscapes" (Weilacher 1999: $56)$, with strongly utopist and critical performances that embed geometric shapes and imaginary topographies in the landscape. They are examples stressing, just as Sverre Fehn did, the formal relationship between design and nature as a way to understand that
Figure 15. Sverre Fehn. Norwegian Glacier Museum, Fjærland, 1989-91. (Source: Fehn, S. and Mauritzen, M. O. 1994. The Norwegian Glacier Center. Living Architecture, 13).

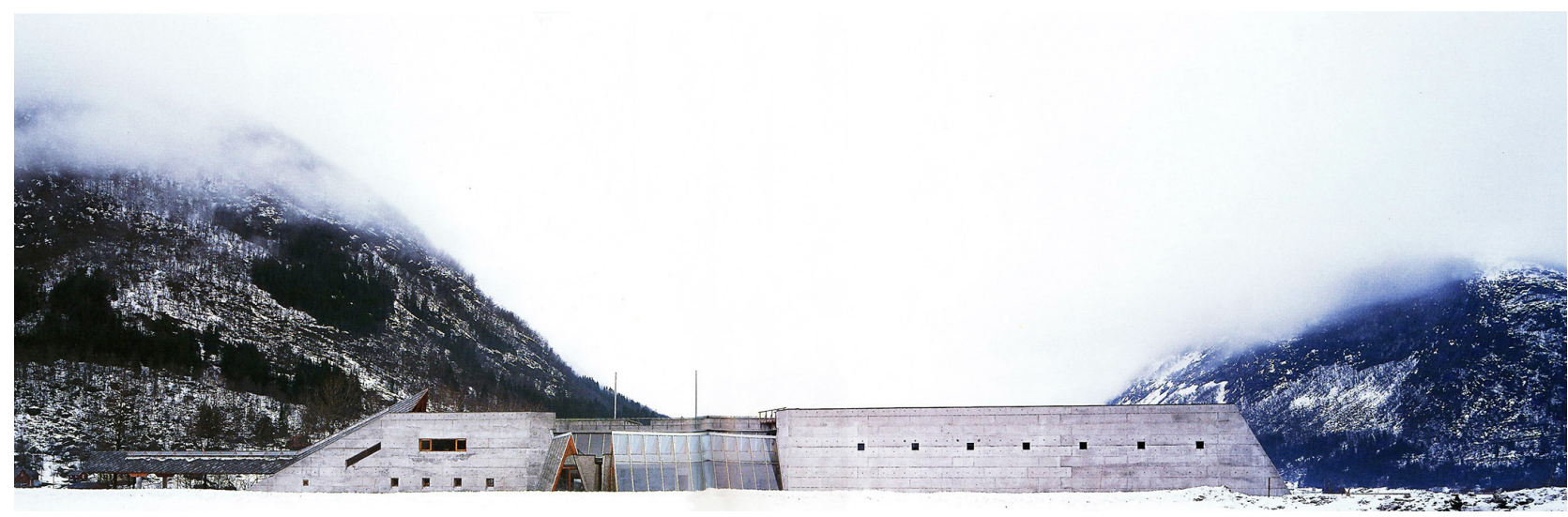



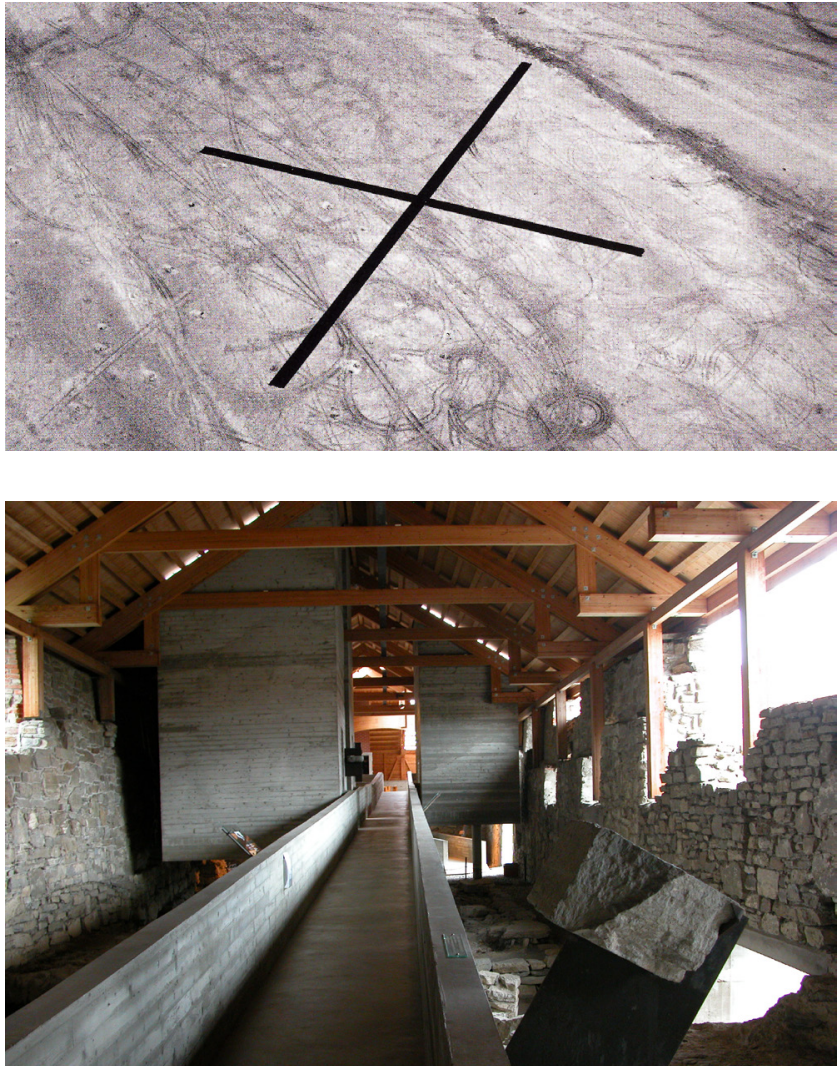
Oppenheim. Relocated Burial, 1978. (Source: Tiberghien, G. A. 1995. Land art. London: Art Data).

Figure 18. Sverre Fehn. Hedmark Mu seum and Bishop's Palace, Hamar, 1967-79. Borrego).

Figure 19. Carl-Viggo Hølmebakk. Sohlbergplassen viewpoint, 2003. Model. (Villalobos 2018: 55).
Figure 17. Dennis (Source: Iván I. Rincón they complement each other. (Rincón-Borrego, I. 2014)

Acting on the setting from the assumptions of Land Art means accepting beforehand the timeless nature of architecture and, likewise, accepting the counterparts of the landscape as being such, its emblematic nature, and the grand scale accompanying it. This attitude is, if possible, even more transcendent if we consider some of the breathtaking Norwegian spots where Sverre Fehn's are placed and the National Tourist Routes Plan projects.

In the Hedmark Museum and Bishop's Palace (1967-79) Sverre Fehn expands the

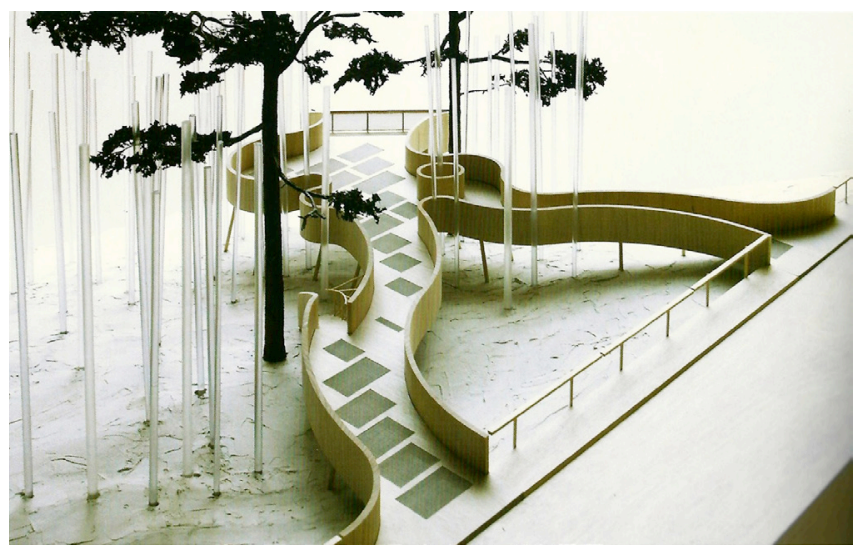

idea of memory of place, faced with a location where, according to him, "the Earth's skin has been dissolved" (Fehn 1994: 11). The setting is the archaeological site of the ancient palace in Hamar, of which barely a few walls in ruins remain, and where the ground gradually disappears as archaeological studies excavate it. Under such circumstances, the architect is focused on two factors: first, on the findings that might be buried in the soil, "objects that are essential for tracing the history of the past"; and second, on the user, under whose steps the land melts. The raison d'être of the museum is thus to mediate between the two to "help the visitor, who should be provided with a horizon, a firm floor", Sverre Fehn stresses, "with the Earth's skin, you shape it, to show that which is hidden in it" (Fehn 1994: 11). The solution comes through a simple system of concrete platforms raised above the ground that are intertwined with the existing walls (figure 18). The blueprint is a setting of architectural structures that the user always views from above, of ruins that are read like a stone book. The museum makes the archaeological site understandable, sutures the cuts, and restores the sensation of a lost place.

The concrete platforms of the Hedmark Museum bring the memory of the Hamar archaeological site to light; and, similarly, Carl-Viggo Hølmebakk's Sohlbergplassen viewpoint (2003) ${ }^{11}$ takes us back to the experiences initially mentioned by Harald Sohlberg in Winternight in Rondane. The architect designs a single concrete platform of curvy lines on the slopes of Antsiøen, a platform that interlaces with the existing fir trees, sidestepping them, adding itself to the forest like a suspended layer that lifts the visitor to the right height to admire the Blue Mountains (figures 19 and 20). The viewpoint harmonizes with the museum, given that both encourage reading the landscape as if it were a palimpsest of memories and experiences. We almost seem to hear Carl-Viggo Hølmebakk, a past student of Sverre Fehn, remembering Fehn's words: "[When] history occurs as a layering of signs, nature and history remember their rhythm and blend together in a single organic reality thanks to architecture" (Fehn 1980: 32$55)$, or perhaps his other motto from the previously-mentioned MIT conference: "the best [architectural] poems have few words" (Fehn 1994: 7). Little more than a sheet of concrete helpfully oriented in the setting, placed to adapt to the trees, is enough to encode the atavistic values of this unforgettable passage of Scandinavian culture. 


\section{Conclusion and Outlook}

Over the last decades, Norway has experienced a change of cycle with respect to its architecture. It has been a change promoted by the institutions thanks to initiatives like the Oslo Fjord Plan and the National Tourist Routes Plan, whose projects have been carried out to a great extent by young, but none-the-less consolidated, architecture studios. Clearly, delving into this new generation would require mentioning Jan Olav Jensen, Rune Grov, Knut Hjeltnes, Hilde Haga, Jensen \& Skodvin, and the Snøhetta team, among many others. The famous project the last group mentioned for the Norwegian $\mathrm{Na}$ tional Opera and Ballet (2000-08) would be the showcase piece, an eloquent representative of the legacy of masters such as Knut Knutsen, Christian Norberg Schulz, and Sverre Fehn. In fact, during the inauguration of the exposition Snøhetta, architecture - landscapes - interiors in May 2009, Jonas Gahr Støre, representing the Norwegian Ministry of Foreign Affairs, indicated that the essence of this change is mainly generational. He emphasized the idea of Norwegian architecture as a way to tell stories and explain the place and the world, a message that (as we have noted) their educators had implicitly endorsed before.

In short, all of them converge directly and indirectly agree on the importance of establishing a relationship with landscape and its memory through architecture. The projects of the National Tourist Routes Plan really began a long time ago in classrooms for workshops like Bygg 3 in Oslo School of Architecture and Design (AHO), ${ }^{12}$ where Per Olaf Fjeld, Neven Fuchs-Mikac, Turid Haaland, Finn Kolstad, Terje Moe, and Ole Frederik Stoveland collaborated together with Sverre Fehn over the years.Or even before, when Sverre Fehn himself reminds us that many of his colleagues were constantly wondering: "What would Knut Knutsen have said?”, (Sverre Fehn 1999: 126).

Jan Olav Jensen, of the architectural firm Jensen \& Skodvin, confirms that, to some extent, everything began in the AHO lecture halls. There, the classes were designed to open the students' minds, "the creative lie" (Jensen 2008: 295): intellectual fictions to channel the project toward the setting: "Whether or not the colourful and often baroque stories ha told in his lectures had any counterpart in life, for many of us who studied with him, there was something cultic both about the

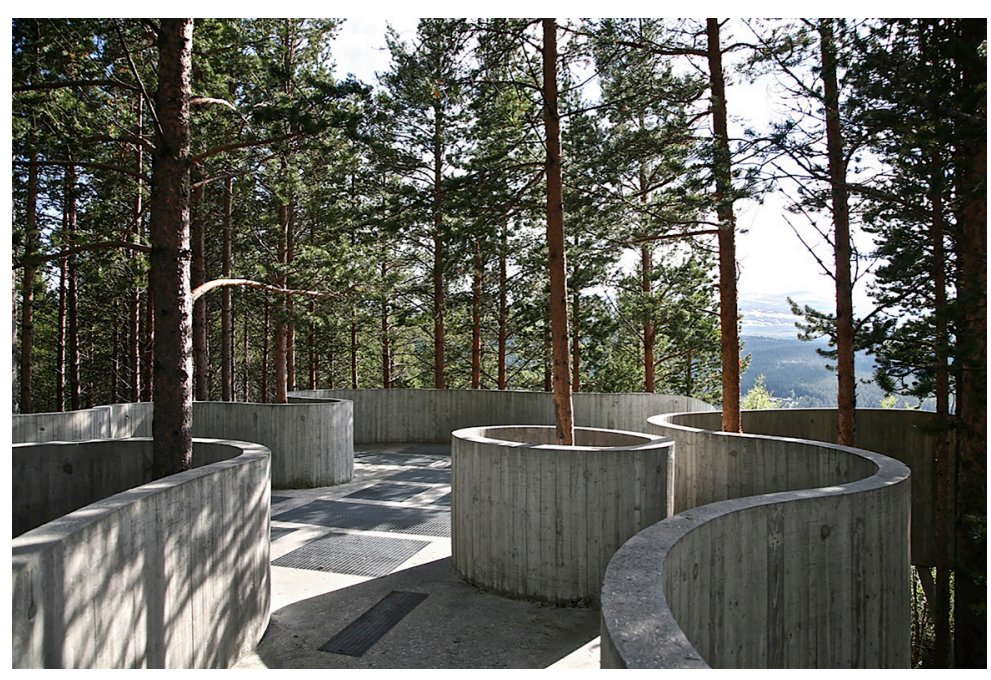

concept of precision an about how far it was possible to take it. It was a matter of uncovering one's inner source." (Jensen, J. O. et al. 2008) and of the world.

\section{Notes}

1 The Oslo Fjord Plan concerns the architectural recovery of 225 hectares of the city's waterfront, which is divided into 13 zones. Its composition includes such notable interventions as the Snøhetta Opera and National Ballet, 2000-08; the unch/Stenersen Museum, by Alberto Herreros; the Deitchman Library in Bjørvika and the urban development of Barcode commissioned from the a-lab team.

2 Since the end of the 90s, architecture in Norway has experienced a change in the cycle promoted by institutions. Initiatives such as the Oslo Fjord Plan or the National Tourist Routes Plan have been developed by young teams of architects, mostly Norwegian. A turning point in this sense were the exhibitions Architect Sverre Fehn: Intuition, Reflection, Construction, in March 2008, and the exhibition Snøhetta, architecture - landscapes - interiors, in May 2009. At the opening of the latter, Jonas Gahr Støre expressed the value of this change. (Yvenes y Madshus 2008).

3 The speech of Jonas Gahr Støre, representative of the Norwegian Ministry of Foreign Affairs, was published on the Norwegian Government's website $h t t p: / / w w w . r e g j e r i n g e n . n o$. The website also contained the working document architecture.now - Norwegian Architectural Policy, which constitutes a statement of intent regarding the identity and architectural aspirations of contemporary Norway.

4 Although Knutsen considers this house a Sorlandhuser, a typical summer house built in a natural setting in southern Norway, the house
Figure 20. Carl-Viggo Hølmebakk. Sohlbergplassen viewpoint, Blue Mountains. (Villalobos 2018: 55). 2003. View towards 
is the opposite, as it is hidden from indiscreet glances unlike other Sorlandhuser, as if it were a secret hiding place. It can only be accessed by knowing the exact place where it is set up because it mimics the rocks and Knutsen hardly leaves any marks that guide the visitor. (Knutsen 1952: 126-129).

5 Inge Dahlman graduated at NLH (Norwegian University of Life Sciences) in 1985. This Norwegian University has historically taught the degree of landscape architect, being in the orbit of the AHO where Inge Dahlman has taught numerous lectures.

6 Jan Olav Jensen and Børre Skodvin graduated at AHO in 1985 and 1988, respectively. Jan Olav Jensen remembers the importance of his AHO professors (Jensen 2008: 295).

7 Arild Wåge graduated at NTH (Norwegian Institute of Technology) in 1975 before it becomes part of the AHO.

8 Although Reiulf Ramstad obtains his PhD at the University of Venice, many of his main partners graduate at the AHO; Anja H. Strandskogen, Christian Skram Fuglset or Anders Tjønneland, among others.

9 Talking about the way Sverre Fehn taught, Per Olaf Fjeld writes "He has a unique ability to visualize and then simplify the most complex thoughts. In this sense, his teaching was similar to Louis Kahn's: they were both seductive, never imperative, in their approach." (Fjeld 2009: 173).

10 The enormous deployment that the German author performs between May 30 and June 5, 1978 ends up being consumed by fire. It is a critical claim of the "fossilized society in which we live, which is capable of wasting enormous sums of money and unlimited resources in the preservation of things and increasing their value" according to Voth himself (Weilacher 1999: 65).

11 Carl-Viggo Hølmebakk graduated at the AHO in 1984 and at Cooper Union in New York 1984-85 AHO's relationship with the Cooper Union wil be intensified through Sverre Fehn's stay at the American University in 1986

12 Bygg 3, which translation would be Building 3, is the didactic block led by Sverre Fehn at the Oslo School of Architecture (AHO). Despite the title, in fact the subject includes the teaching of design of projects, theoretical classes of composition and history of architecture. Per Olaf Fjeld, Neven Fuchs-Mikac, Turid Haaland, Finn Kolstad, Terje Moe and Ole Frederik Stoveland collaborated in this laboratory over the years.

\section{References}

A.A.V.V. 2009. Architecture now. Norwegian Architectural Policy. Oslo: Ministry of Culture and Church Affairs.

Álvarez-Álvarez, D. 2018. Paisajes Románticos | Miradas Contemporáneas. In Villalobos, D (ed.), Arquitectura y Paisaje. Carreteras que emocionan. Arquitectura y Paisaje en la Noruega Contemporánea. Valladolid: Universidad de Valladolid y Real Embajada Noruega en España.

FEHN, Sverre. 1980. The tree and the horizon. Spazio \& Societa, 10: 32-55.

Fenn, S. 1999. Knut Knutsen. In Nicola F., Giarde1lo, P. and Postiglione, G. Arne Korsmo - Knut Knutsen. Due Maestri del Nord. Roma: Officina Ed.

Fenn, Sverre. 1994. The Skin, the Cut \& the Bandage. In Anderson, S. (ed.) The Pietro Belluschi Lectures. Boston: The MIT Press.

FJELD, Per Olaf. 2009. Sverre Fehn: the pattern of thoughts. New York: The Monacelli Press.

FLORA, N. 1999. Between Artefact and Nature: the Domestic Project of A. Korsmo and K. Knutsen. In Nicola F., Giardello, P. and Postiglione, G. Arne Korsmo - Knut Knutsen. Due Maestri del Nord. Roma: Officina Ed.

Jensen, J. O. 2008. Affinity. In Andersen, M. A. (ed.) Nordic Architects Write. A Documentary Anthology. New York: Routledge. 295.

Knutsen, Knut. 1952. A holiday house. Byggekunst, 8: 126-129.

Knutsen, K. 1961. People in Focus. In Andersen, M. A. (ed.), Nordic Architects Write. A Documentary Anthology. New York: Routledge. 249.

Norberg Schulz, Christian. 1971. Existence, Space and Architecture. London: Praeger Publishers.

Norberg Schulz, Christian. 1979. Genius Loci. Pae saggio, Ambienta Architettura. Milan: Electa.

Norberg Schulz, Christian. 1996. Nightlands. London: The MIT Press.

Norberg Schulz, Christian. 2000. Principles of Modern Architecture. London: A. Papadakis.

REF. WEB 2. www.regjeringen.no/en/search.html?querystring $=\mathrm{Sn} \% \mathrm{C} 3 \% \mathrm{~B} 8$ hetta,+ architecture+\%E2\%80\%93+landscapes+\%E2\%80\%93+interiors\&id=86008 [visited January, 2013].

Rincón-Borrego, I. 2014. The Skin, the Cut, the Bandage. Legado y crítica en Sverre Fehn. In critic|all I International Conference on Architectural Design \& Criticism. Madrid: critic|all PRESS. 978 - 986.

Rosenblum, Robert. 1993. La pintura moderna y la tradición del romanticismo. De Friedrich a Rothko. Madrid: Alianza.

Rønning, Svein. 2016. Nasjonale turistveger. Die Norwegischen Landschaftsrouten National. Tou rist Routes in Norway. Oslo: Forlaget Press.

Villalobos, Daniel (ed.). 2018. Arquitectura y Paisaje. Carreteras que emocionan. Arquitectura y paisaje en la Noruega contemporánea. Valladolid: Universidad de Valladolid y Real Embajada Noruega en España. 
Weilacher, Udo. 1999. Between Landscape Architecture and Land Art. Basilea: Birkhäuser.

Yvenes, Marianne and Madshus, Eva (ed.). 2008. Architect Sverre Fehn: Intuition, Reflection, Construction. Oslo: The National Museum of Art, Architecture and Design.

Fecha final recepción articulos: 25/04/2019

Fecha aceptación: 01/07/2019

Artículo sometido a revisión por dos revisores independientes por el método doble ciego. 